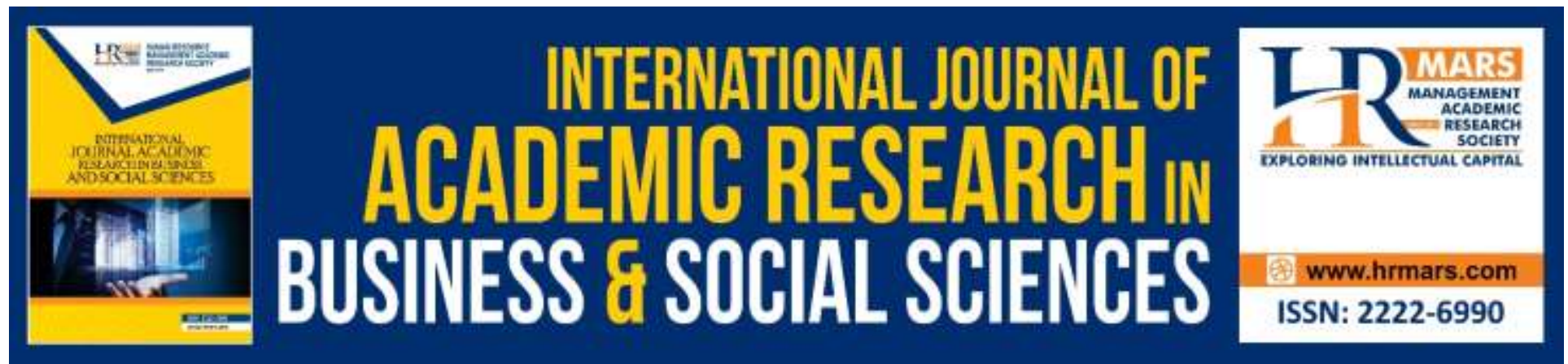

\title{
The Impact of Electronic Word of Mouth Instagram as Recommendations Halal Culinary Tours in Banda Aceh
}

Nanda Khalisa, Dr. Teuku Meldi Kesuma

To Link this Article: http://dx.doi.org/10.6007/IJARBSS/v8-i5/4481

DOI:10.6007/IJARBSS/v8-i5/4481

Received: 02 March 2018, Revised: 29 Mar 2018, Accepted: 21 April 2018

Published Online: 03 May 2018

In-Text Citation: (Khalisa \& Kesuma, 2018)

To Cite this Article: Khalisa, N., \& Kesuma, T. M. (2018). The Impact of Electronic Word of Mouth Instagram as Recommendations Halal Culinary Tours in Banda Aceh. International Journal of Academic Research in Business and Social Sciences, 8(5), 1028-1046.

Copyright: (C) 2018 The Author(s)

Published by Human Resource Management Academic Research Society (www.hrmars.com)

This article is published under the Creative Commons Attribution (CC BY 4.0) license. Anyone may reproduce, distribute, translate and create derivative works of this article (for both commercial and non-commercial purposes), subject to full attribution to the original publication and authors. The full terms of this license may be seen at: http://creativecommons.org/licences/by/4.0/legalcode

Vol. 8, No. 5, May 2018, Pg. 1028 - 1046

Full Terms \& Conditions of access and use can be found at http://hrmars.com/index.php/pages/detail/publication-ethics 


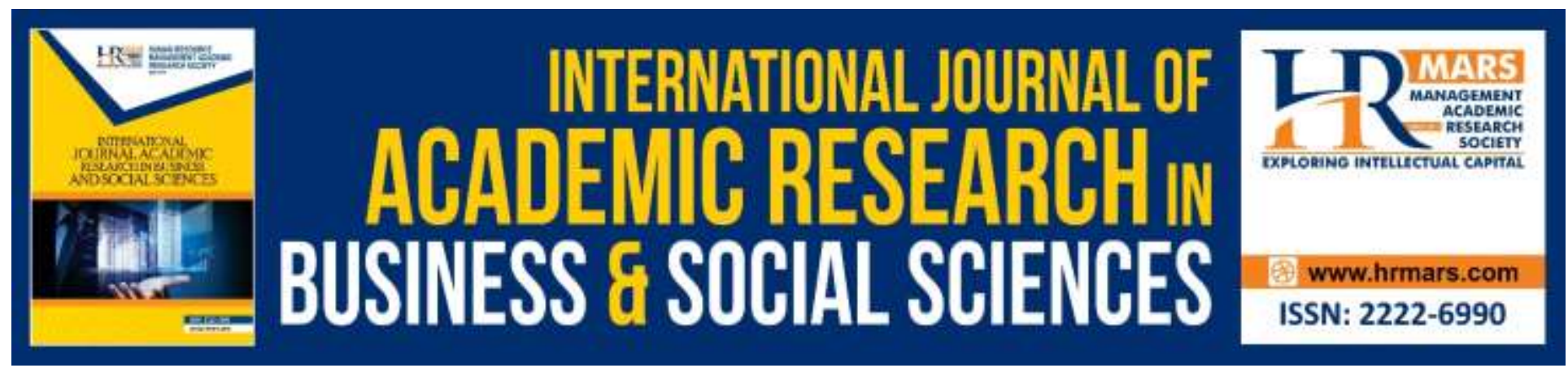

\title{
The Impact of Electronic Word of Mouth Instagram as Recommendations Halal Culinary Tours in Banda Aceh
}

\author{
Nanda Khalisa, Dr. Teuku Meldi Kesuma \\ Economics \& Business Faculty, Syiah Kuala University, Banda Aceh, Indonesia \\ Email: nandakhalisa12@yahoo.com, teukumeldi@unsyiah.ac.id
}

\begin{abstract}
The content of instagram account "Kulineratjeh" is about review or recommendations halal culinary tours in Banda Aceh and the types Aceh's food typical. Instagram account "Kulineratjeh" is one of the media provider information for the halal foodies in Banda Aceh, so review and comments on instagram account "Kulineratjeh" can influence consumers in purchase intention. The new phenomenon is going on consumers halal foodies in Banda Aceh is before they visit cafe or restaurant, consumers looking for information and review from instagram account "Kulineratjeh" so The prospective consumer get Electronic Word of Mouth (E-WOM) leading to do purchase intention. The phenomenon has caused E-WOM activity growing at instagram account "Kulineratjeh". Promotion activity from e-WOM in instagram account "Kulineratjeh" and positif image as brand image instagram account "Kulineratjeh" where it can be seen from the types of food promoted is halal food in Banda aceh and surrounding make researches interested to do the research about the phenomenon the impact of e-WOM and brand image growing on instagram account "Kulineratjeh" to consumer purchase intention. The purpose of this study is to analyze the impact of E-WOM to purchase intention through the brand image as a mediating variable. Data collection method is used questionnaire as instrumentand using non probability sampling method, sample in this reserach is 100 followers instagram account "Kulneratjeh". The collected data was analyzed using SmartPLS 2.0 software.
\end{abstract}

Keywords: Electronic Word of Mouth, Purchase Intention, Brand Image.

\section{Introduction}

The development of technology and internet in this era of globalization has changed the paradigm of the society to be more practical so growth and internet users are increasing rapidly every year. Based on research conducted by e-marketer, Indonesia was ranked 6th in the world in terms of internet users (www.kompas.com). Based on the growth projections led to increasingly advanced and the development of social media around the world, including 
Indonesia. Social media is a computer-based tool that allows people to create, share, or exchange information, ideas and images / video in the community and virtual network. (Wikipedia.com). The presence of internet and social media cause the entrepreneurs more creative in promoting their business so that entrepreneurs can utilitize internet and social media as a media campaign for businesses that are run either by using a computer, notebook, or smartphone. This is due to the promotion through social media effectively increase the purchase intentions. Realizing the power of social media, marketers use it to approach consumers (Hendriyani, Jane, Ceng, Utami, Priskila \& Anggita, 2013).

Based on a survey of the number of social media users conducted by Jakpat, instagram is one of the second largest number of social media users after facebook. (http://blog.jakpat.net/en/). This makes the business people prefer instagram as a media campaign for the business run. By using instagram, business people can share photos of their products accompanied by a caption that explains what they're sharing photos.

Use of instagram on promoted business or product can provide spesific information for the consumer. In addition, promotions through instagram can also lead to communication related to photos of products or services that are shared. Communication happens on instagram can be seen through the comments on the post photos so that it indicated that word of mouth (WOM) in electronic form, or better known as electronic word of mouth (e-WOM).

Electronic word of mouth (e-WOM) is the statement made by actual customers, potential customers, or consumers before the product or the company where this information is available to the people or institutions via the internet (Thurau, Gwinner, Walsh \& Gremler, 2004). According to research conducted by Jalilvand (2012), opinion on e-WOM are considered more effective than traditional WOM, this because e-WOM provide coverage which is wider than the traditional WOM. E-WOM began to be considered important because consumers are increasingly active in finding and gathering information before forming purchase intentions (Zhang \& Tran, 2009).

To minimize the risk of unwanted purchases, usually before making a purchase consumers first seek review and written opinion in the comments field instagram. It is also found on instagram account "Kulineratjeh".

The purpose of making instagram account "Kulineratjeh" is as reference material for culinary lovers in Banda Aceh especially to find cafe and other Acehnese food so that account is one of account containing review or recommendation of halal culinary tour in Banda Aceh and other types of Acehnese food. Instagram account "Kulineratjeh" is one of the media information providers for halal food lovers in Aceh, so the reviews and comments on instagram account "Kulineratjeh" is considered to affect consumers in the purchase intentions.

By having a number of follower as many as 53.500 accounts make businesses want to do paid promote or paid promotion on instagram account "Kulineratjeh". Almost all business owners who did paid promote the instagram account "Kulineratjeh" also has a special instagram account to a business carried on. It aims to increase the popularity of the type of business owned. Online popularity of the restaurant is very important, because it can reflect the potential demand for future products, for product review online is a growing phenomenom that gives an important role in consumer purchasing decisions (Zhang et al, 2010).

The new phenomenon that happens to consumers of halal culinary lovers in Banda Aceh is before they visit the cafe or restaurant, they seek first information and review of instagram account 
"Kulineratjeh" so that prospective customers get e-WOM that leads to the intention to make a purchase. This can be seen from the comments that exist on each post photo on instagram account "Kulineratjeh". In addition, every new photo post on instagram account "Kulineratjeh", the prospective consumers always provide comments in the form of invitations and statements to relatives to make a purchase.

The phenomenon has changed the purchasing behavior of online marketing as proposed by AISAS theory. Based on the theory of AISAS, at the time before making a purchase, consumers begin to be aware of the product (Attention), then they start interested (Interest), followed by the process of searching information through the internet (Search), and then consumers take action in the form of purchasing product (Action) and the last is send a review via internet after using product (Share). This theory has indicated a shift in consumer behavior online (Heriyani, et all, 2013). From the AISAS process enables the emergence of e-WOM activity that is when the consumer provides reviews about the products that they consume.

E-WOM made by consumers or potential consumers can not be separated from the brand image. Brand image is a set of memories in the mind of consumers about a brand, whether it is positive or negative (Sangadji \& Sopiah, 2013:327). This is as proposed by Jalilvand (2012) in his research that e-WOM most affect brand image. In addition, Jatmika (2014) also said that e-WOM positive effect on brand image.

Based on the phenomenon of Banda Aceh people who are actively seeking the latest culinary information available in Banda Aceh through reviews on instagram accounts "Kulineratjeh" has led to e-WOM activities that developed on intagram account "Kulineratjeh". Promotion activity through e-WOM that has been developed on social media instagram account "Kulineratjeh" and the positive image instagram account "Kulineratjeh" where it can proven from the types of food promoted is halal food in Banda aceh and surrounding make researches interested to do the research about the phenomenon the impact of e-WOM and brand image growing on instagram account "Kulineratjeh" to consumer purchase intention.

The purpose of this study were: (1) To know the effect of e-WOM on instagram account "Kulineratjeh" to consumer purchase intentions, (2) To know the effect of e-WOM on instagram account "Kulineratjeh" to brand image instagram account "Kulineratjeh", (3) To know the effect of brand image of instagram account "Kulineratjeh" to consumer purchase intentions, (4) To know the effect of e-WOM on instagram account "Kulineratjeh" to consumer purchase intentions through brand image instagram account "Kulineratjeh" as mediation variable.

\section{Empirical Background}

\section{Previous Research on The Effect of e-WOM to Consumer Purchase Intention}

Electronic word of mouth (e-WOM) is the statement made by actual customers, potential customers, or consumers before the product or the company where this information is available to the people or institutions via the internet

e-WOM is usually done through via internet as in social media. Opinion on e-WOM is considered more effective than traditional WOM because e-WOM has a wider range than traditional WOM. Based on research conducted by Jalilvand (2012), e-WOM is growing very influential on consumer purchase intention. In addition, other research conducted by Gozali and Ruslim (2012) also stated that there is significant e-WOM influence on consumer purchase intention. 
Based on other research conducted by Jatmika (2014), e-WOM has significant effect on consumer purchase intention. In addition, other research conducted by Kauthar and Hashim (2015) states e-WOM influences consumer reactions in making purchasing decisions.

\section{Previous Research on The Effect of e-WOM to Brand Image}

E-WOM is growing in a product is closely related to the brand image. The better or the positive the e-WOM develops, the brand image of product. Similiarly, the worse or negative e-WOM that develops can cause destrtuction of a the brand image of a product.

Based on the results of research conducted by Nurkholis Majid, e-WOM influence on brand image.the other study was conducted by Samuel and Lianto (2014) also stated that e-WOM directly affect the brand image. Based on research conducted by Jalilvand (2012), e-WOM is the most effective factor influencing brand image. The other study was conducted by Jatmika (2014), stating that e-WOM is also the most effective factor in influencing brand image.

\section{Previous Research on Brand Image to Consumer Purchase Intention}

Brand image is a set of brand association formed in the minds of consumers. In other words, brand image is a set of memories in the minds of consumers about a brand, whether it is positive or negative (Sangadji \& Sopiah, 2013:327).

Brand image a belief held by consumers with regard to the brand. Customers may develop a series of brand trusts regarding the position of each brand according to their respective attributes. Confidence brand shaping brand image. Every customer has a certain impression on the brand, which can arise after seing, hearing, reading, or tasting his own product brand (Samuel \& Lianto, 2014).

The research conducted by Jalilvand and Samiei (2012), gives results that brand image influencing consumers' purchasing intentions. In addition, another study conducted by Jatmika (2014) also states that brand image significantly influenced consumers purchasing intentions. Based on the result of Samuel and Lianto (2014). brand image influencing consumer to buy. Reserach conducted by Bhakar, Bhakar \& Bhakar (2013) also states that the brand image positive influence on consumer purchase intentions.

A positive brand image provide benefits for producers to better known consumers. In other words, consumers will choose to buy products that have a good image. If brand image is negative, consumers tend to consider even more when going to buy the product. 


\section{Research Model and Hypothesis}

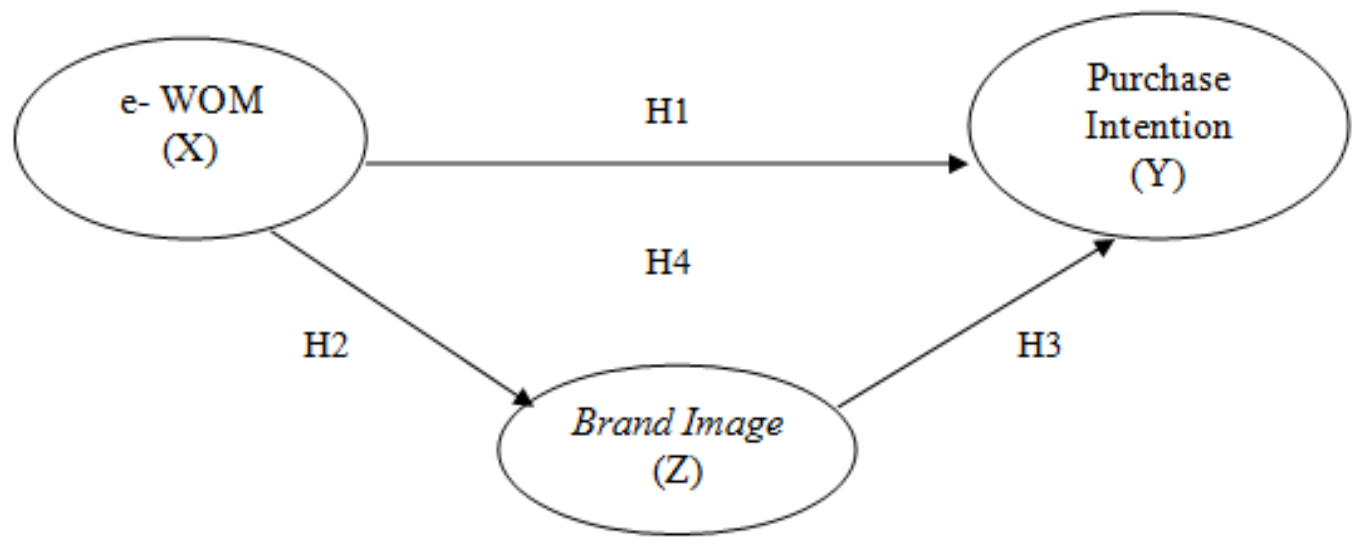

Figure 1: Reseacrh Model

Based on theresearch framework, the hypothesis formulation for this research is:

$\mathrm{H} 1$ : e-WOM on instagram account "Kulineratjeh" affect on consumer purchase intentions.

$\mathrm{H} 2$ : e-WOM on instagram account "Kulineratjeh" effect on brand image instagram account "Kulineratjeh".

H3: Brand image instagram account "Kulineratjeh" affect on consumer purchase intentions.

H4: e-WOM on instagram account "Kulineratjeh" affect on consumer purchase intentions through brand image instagram account "Kulineratjeh" as mediating variabel.

\section{Research Methodology}

The population in this study is the users of instagram account in Banda Aceh. The technique used in sampling in this research is nonprobability sampling method. According to Hair et al (2006) in Abdillah \& Jogiyanto (2015:183), to acquire $80 \%$ at alpha $5 \%$, the sample size for each indicator a minimum of 5 samples or up to 10 samples for the estimation model. The number of indicators in this study are as 20 indicators and multiplied by 5 then the number of samples obtain are as many as 100 samples. The sampling is also supported by Roscoe's theory that the sample size is good is over 30 and less than 500 (Sekaran \& Bougie, 2009:296).

This research uses questionnaire, where the respondent's answer is measured by using likert scale. The analysis is using SEM (Structural Equation Modeling).

Data analysis equipment used in this research is SEM-based variants its called Partial Least Square (PLS). According to Hussein (2015), PLS can be used although independent variables, dependent varibles and mediation variabel of each reseacrh amount to one, in addition the sample can range from 30-100 samples.

In PLS, an indicator is considered valid if it has a loading factor 0,7. However, because this study is the development of the loading factor value above 0,6 is acceptable, and the value of average variance extract (AVE) above 0,5 (Abdillah \& Jogiyanto, 2015:195).

In the approach to SEM/PLS by Willy Abdillah and Jogiyanto (2015:196) a measurement has met the convergent validity if it qualifies if it has a minimum communality value of 0,5 and an AVE at least 0,5 . The discriminant validity evaluation is in two stages. First, viewing the value of cross 
loading and comparing the correlation square value between the construct with the AVE root (Abdillah \& Jogiyanto, 2015:195). Reliability test in PLS is use cronbach's alpha and composite reliability.

According to Abdillah and Jogiyanto $(2015: 197)$ the structural model in the PLS is evaluated by using $\mathrm{R}^{2}$ for the dependent construct, the path or t-values of each path for the significance test between constructs in the structural model.

The value of the path coefficient or inner model shows the level of significance path or inner model shown by the value of T-statistics above 1,64 for testing at alpha $5 \%$ and power $80 \%$ (Hair et al, 2008 in Abdillah \& Jogiyanto, 2015:197).

\section{Profile of Respondents}

Tabel 1: Profile Of Respondents

\begin{tabular}{|c|c|c|c|c|}
\hline $\begin{array}{l}\mathbf{N} \\
\mathbf{0}\end{array}$ & $\begin{array}{c}\text { Characteristi } \\
\text { cs }\end{array}$ & Clasification & $\begin{array}{l}\text { Number of } \\
\text { Responden }\end{array}$ & $\begin{array}{c}\text { Percentag } \\
\text { e }\end{array}$ \\
\hline \multirow{3}{*}{1.} & \multirow{2}{*}{ Gender } & Male & 43 & $43 \%$ \\
\hline & & Female & 57 & $57 \%$ \\
\hline & \multicolumn{2}{|c|}{ Amount } & 100 & $100 \%$ \\
\hline \multirow{5}{*}{2.} & \multirow{4}{*}{ age } & $18-23$ & 58 & $58 \%$ \\
\hline & & $24-28$ & 35 & $35 \%$ \\
\hline & & $29-33$ & 6 & $6 \%$ \\
\hline & & $>33$ & 1 & $1 \%$ \\
\hline & \multicolumn{2}{|c|}{ Amount } & 100 & $100 \%$ \\
\hline \multirow{3}{*}{3.} & \multirow{2}{*}{$\begin{array}{l}\text { Marriage } \\
\text { Status }\end{array}$} & Married & 14 & $14 \%$ \\
\hline & & Single & 86 & $86 \%$ \\
\hline & \multicolumn{2}{|c|}{ Amount } & 100 & $100 \%$ \\
\hline \multirow{5}{*}{4.} & \multirow{4}{*}{$\begin{array}{l}\text { Level of } \\
\text { Education }\end{array}$} & $\begin{array}{c}\text { Senior High } \\
\text { School }\end{array}$ & 35 & $35 \%$ \\
\hline & & Diploma & 13 & $13 \%$ \\
\hline & & Bachelor & 43 & $43 \%$ \\
\hline & & Postgraduate & 9 & $9 \%$ \\
\hline & \multicolumn{2}{|c|}{ Amount } & 100 & $100 \%$ \\
\hline \multirow{6}{*}{5.} & \multirow{5}{*}{$\begin{array}{l}\text { Type of } \\
\text { Work }\end{array}$} & Civil Servant & 3 & $3 \%$ \\
\hline & & $\begin{array}{c}\text { Private } \\
\text { Employees }\end{array}$ & 13 & $13 \%$ \\
\hline & & Students & 60 & $60 \%$ \\
\hline & & Businessman & 14 & $14 \%$ \\
\hline & & etc & 10 & $10 \%$ \\
\hline & \multicolumn{2}{|c|}{ Amount } & 100 & $100 \%$ \\
\hline
\end{tabular}


INTERNATIONAL JOURNAL OF ACADEMIC RESEARCH IN BUSINESS AND SOCIAL SCIENCES

Vol. 8, No. 5, May 2018, E-ISSN: 2222-6990 @ 2018 HRMARS

\section{Outer Model Testing}

\section{Convergent Validity Test Result}

The test is consists of two things is to see the value of the loading factor and the value of $t$ statistic and the value of average variance extracted (AVE).

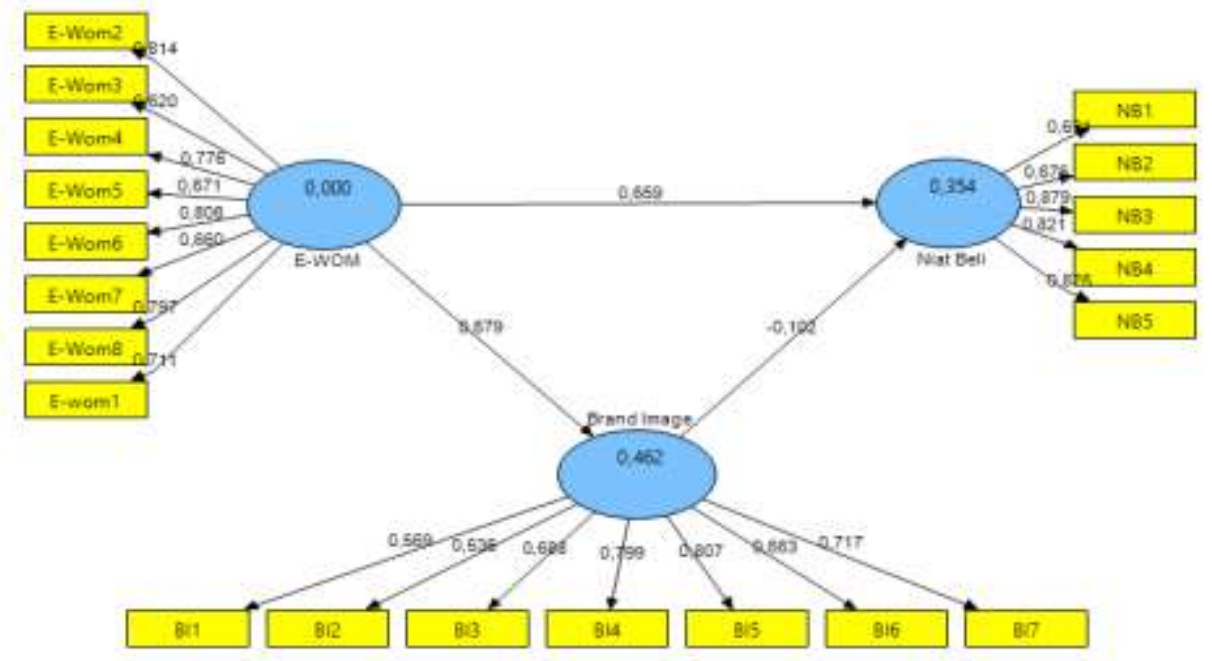

Figure 2: Display Ouput Indicator Loading

From the look of the output indicator loading above shows that all indicators of the variable eWOM and purchase intentions are qualified convergent validity to construct reflective by loading above 0,60 , while two indicators brand image is not feasible because it has a loading below 0,60 so that the $\mathrm{BI} 1$ and $\mathrm{BI} 2$ indicators are omitted in the model. After $\mathrm{B} 1$ and $\mathrm{B} 2$ are ommited in the model, then retest with the following results.

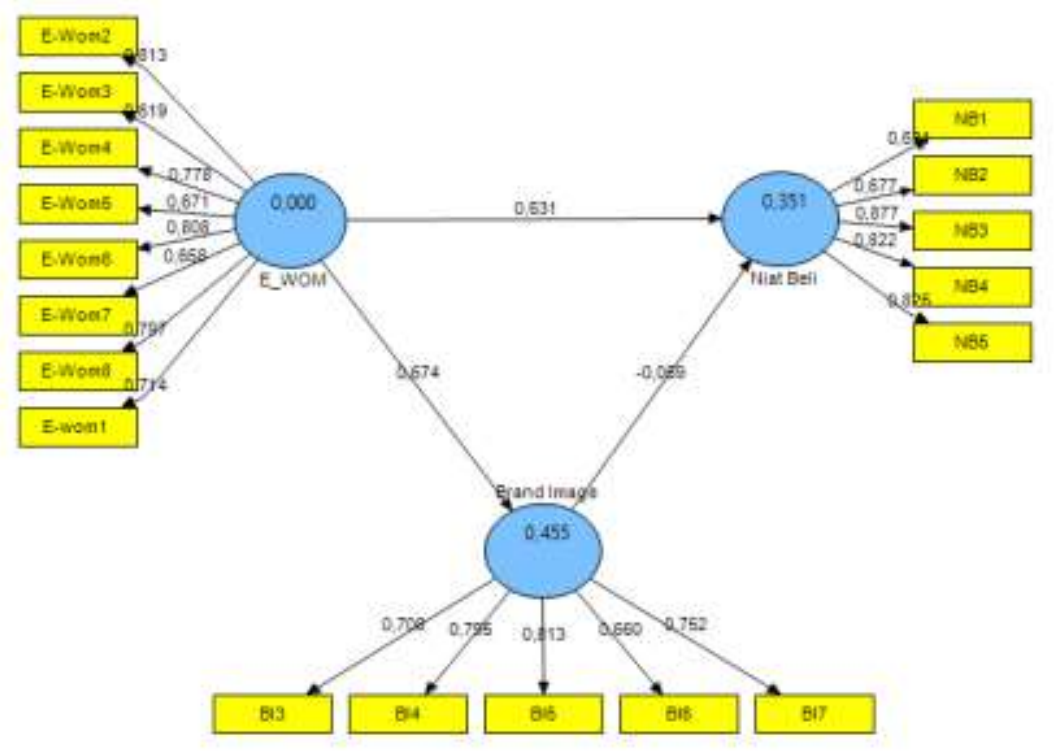

Figure 3: Change Output View Loading Indicator 
INTERNATIONAL JOURNAL OF ACADEMIC RESEARCH IN BUSINESS AND SOCIAL SCIENCES Vol. 8, No. 5, May 2018, E-ISSN: 2222-6990 ㄷ 2018 HRMARS

Table 2

Display Outer Loadings

\begin{tabular}{|c|c|c|c|c|c|}
\hline Indicator & $\begin{array}{c}\text { Original } \\
\text { Sample } \\
\text { (O) }\end{array}$ & $\begin{array}{c}\text { Sample } \\
\text { Mean } \\
\text { (M) }\end{array}$ & $\begin{array}{c}\text { Standard } \\
\text { Deviation } \\
\text { (STDEV) }\end{array}$ & $\begin{array}{c}\text { Standard } \\
\text { Error } \\
\text { (STERRI) }\end{array}$ & $\begin{array}{c}\text { T Statistic } \\
\text { (IO/STERRI) }\end{array}$ \\
\hline E-WOM1 & 0,7139 & 0,7083 & 0,0626 & 0,0626 & 11,3977 \\
\hline E-WOM2 & 0,8125 & 0,8165 & 0,0365 & 0,0365 & 22,2216 \\
\hline E-WOM3 & 0,6189 & 0,6217 & 0,0637 & 0,0637 & 9,7098 \\
\hline E-WOM4 & 0,7778 & 0,7847 & 0,0407 & 0,0407 & 19,0844 \\
\hline E-WOM5 & 0,6708 & 0,6780 & 0,0750 & 0,0750 & 8,9347 \\
\hline E-WOM6 & 0,8078 & 0,8123 & 0,0363 & 0,0363 & 22,2178 \\
\hline E-WOM7 & 0,6583 & 0,6630 & 0,0765 & 0,0765 & 8,5950 \\
\hline E-WOM8 & 0,7966 & 0,7946 & 0,0443 & 0,0443 & 17,9572 \\
\hline NB1 & 0,6311 & 0,6302 & 0,0758 & 0,0758 & 8,3190 \\
\hline NB2 & 0,6769 & 0,6749 & 0,0839 & 0,0839 & 8,0670 \\
\hline NB3 & 0,8772 & 0,8757 & 0,0237 & 0,0237 & 36,9397 \\
\hline NB4 & 0,8218 & 0,8222 & 0,0536 & 0,0536 & 15,3096 \\
\hline NB5 & 0,8250 & 0,8239 & 0,0310 & 0,0310 & 26,6013 \\
\hline BI3 & 0,7080 & 0,7117 & 0,0590 & 0,0590 & 11,9808 \\
\hline BI4 & 0,7953 & 0,7907 & 0,0615 & 0,0615 & 12,9163 \\
\hline BI5 & 0,8130 & 0,8114 & 0,0393 & 0,0393 & 20,6673 \\
\hline BI6 & 0,6600 & 0,6503 & 0,0822 & 0,0822 & 8,0286 \\
\hline BI7 & 0,7518 & 0,7545 & 0,0453 & 0,0453 & 16,5647 \\
\hline SOWres
\end{tabular}

Source: Output SmartPLS 2.0, 2016.

An indicator can be said to be valid if an indicator loading factor value above 0,7 but a value above 0,60 is acceptable (Abdillah \& Jogiyanto, 2015:195). In addition, the indicators considered valid if the value of $t$ statistics more than 2,0 (Yamin \& Kurniawan, 2011;182). Based on the model test results above shows that all indicators have a loading factor value above 0,60 , and all the loading factor has value $t$ statistics more than 2.0 so it clearly has significant validity.

The last testing of convergent validity is viewed outputs AVE. Construct that has a good convergent validity is when the value AVE and communality more than 0,50 (Abdillah \& Jogiyanto, 2015:206). Here is the output AVE and communality.

Table 3

AVE Results

\begin{tabular}{|c|c|c|c|}
\hline Variable & AVE & Communality & Redundancy \\
\hline Brand Image & 0,5591 & 0,5591 & 0,2500 \\
\hline Purchase Intention & 0,5964 & 0,5964 & $-0,0276$ \\
\hline E-WOM & 0,5411 & 0,5411 & 0,000 \\
\hline
\end{tabular}

Source: Output SmartPLS 2.0, 2016.

Based on the table 3, construck brand image, purchase intention, dan e-WOM has a value AVE 
INTERNATIONAL JOURNAL OF ACADEMIC RESEARCH IN BUSINESS AND SOCIAL SCIENCES

Vol. 8, No. 5, May 2018, E-ISSN: 2222-6990@ 2018 HRMARS

and communality more than 0,50 to be valid.

\section{Discriminant Validity Test Results}

Discriminant validity evaluation carried out in two stages, which saw the value of cross loading and comparing the value of the square of the correlation between the construct with roots AVE. Further, reflective indicators also need to be tested by cross loading discriminant validity as follow.

Table 4

Cross Loading Results Display

\begin{tabular}{|c|c|c|c|}
\hline Indikator & Brand Image & E-WOM & Niat Beli \\
\hline E-WOM1 & 0,4748 & $\mathbf{0 , 7 1 3 9}$ & 0,5346 \\
\hline E-WOM2 & 0,5919 & $\mathbf{0 , 8 1 2 5}$ & 0,4407 \\
\hline E-WOM3 & 0,5459 & $\mathbf{0 , 6 1 8 9}$ & 0,2926 \\
\hline E-WOM4 & 0,4984 & $\mathbf{0 , 7 7 7 8}$ & 0,5327 \\
\hline E-WOM5 & 0,4140 & $\mathbf{0 , 6 7 0 8}$ & 0,4631 \\
\hline E-WOM6 & 0,4813 & $\mathbf{0 , 8 0 7 8}$ & 0,4422 \\
\hline E-WOM7 & 0,4334 & $\mathbf{0 , 6 5 8 3}$ & 0,2791 \\
\hline E-WOM8 & 0,5137 & $\mathbf{0 , 7 9 6 6}$ & 0,4393 \\
\hline NB 1 & 0,1955 & 0,2836 & $\mathbf{0 , 6 3 1 1}$ \\
\hline NB 2 & 0,2273 & 0,3674 & $\mathbf{0 , 6 7 6 9}$ \\
\hline NB 3 & 0,2329 & 0,5155 & $\mathbf{0 , 8 7 7 2}$ \\
\hline NB 4 & 0,3409 & 0,4539 & $\mathbf{0 , 8 2 1 8}$ \\
\hline NB 5 & 0,3822 & 0,5798 & $\mathbf{0 , 8 2 5 0}$ \\
\hline BI 3 & $\mathbf{0 , 7 0 8 0}$ & 0,4486 & 0,3017 \\
\hline BI 4 & $\mathbf{0 , 7 9 5 3}$ & 0,4962 & 0,2398 \\
\hline BI 5 & $\mathbf{0 , 8 1 3 0}$ & 0,5557 & 0,2408 \\
\hline BI 6 & $\mathbf{0 , 6 6 0 0}$ & 0,4065 & 0,2047 \\
\hline BI 7 & $\mathbf{0 , 7 5 1 8}$ & 0,5812 & 0,3588 \\
\hline
\end{tabular}

Source: Output SmartPLS 2.0, 2016.

The criterion in cross loading is that each indicator that measures its construct must be correlated higher with its construct compared to other constructs (Yamin \& Kurniawan, 2011;183). Based on the results of cross loading tables above, each indicator correlates higher with each construct compared to other constructs, so it has good discriminant validity.

The next evaluation is to compare the correlation between constructs with AVE roots. The results is in the bellow.

Table 5

Interconnect Variable Correlations

\begin{tabular}{|c|c|c|c|}
\hline & Brand Image & E-WOM & Purchase Intention \\
\hline Brand Image & 1 & & \\
\hline E-WOM & 0,6743 & 1 & \\
\hline Purchase Intention & 0,3663 & 0,5911 & 1 \\
\hline
\end{tabular}

Source: Output SmartPLS 2.0, 2016. 
Table 6

AVE Root

\begin{tabular}{|c|c|c|}
\hline Variable & AVE & Akar AVE \\
\hline Brand Image & 0,5591 & 0,7477 \\
\hline E-WOM & 0,5411 & 0,7355 \\
\hline Purchase Intention & 0,5964 & 0,7722 \\
\hline
\end{tabular}

Source: Output SmartPLS 2.0, 2016.

Based on the above table it can be seen that the maximum correlation e-WOM construct with other constructs is equal to 0,5911 ; while the value of AVE roots is 0,7355 . Maximum correlation Brand Image construct with other construct that equal to 0,6743; while the value of AVE roots is 0,747 . Because the AVE root value of both constructs is greater than the correlation value between constructs, it is said to have good discriminant validity.

Table 7

Reliability Test Results

\begin{tabular}{|c|l|c|c|c|}
\hline No. & \multicolumn{1}{|c|}{ Variable } & Composite Reliability & Cronbach's Alpha & Information \\
\hline 1. & $\begin{array}{l}\text { Electronic Word of Mouth } \\
\text { (E-WOM) }\end{array}$ & 0,9033 & 0,8768 & Reliable \\
\hline 2. & Purchase Intention & 0,8792 & 0,8289 & Reliable \\
\hline 3. & Brand Image & 0,8631 & 0,8020 & Reliable \\
\hline
\end{tabular}

Source: Output SmartPLS 2.0, 2016.

Based on the table 7, it can be seen that the composite reliability have qualified is worth over 0,70 . Similarity, the value of cronbach's alpha has been in accordance with the criteria above 0,60 .

Thus all questions used in this research variable can be said to be reliable because it has met the credibility of the standard cronbach's alpha value greater than 0,60 and composite reliability above 0,70 .

Overall, the results of the measurement model (outer model) have been qualified so that this reserach can be continued to the structural model (Inner model).

\section{Structural Model Testing (Inner Model)}

This test is conducted to see the relationship between the interconnectivity, significance and $r$ square of the research model. Here is the R-square value of the construct.

Table 8

The Results of $R$-square

\begin{tabular}{|l|c|}
\hline \multicolumn{1}{|c|}{ Variable } & $\mathbf{R}^{\mathbf{2}}$ \\
\hline Brand Image & 0.4547 \\
\hline Purchase Intention & 0.3514 \\
\hline $\begin{array}{l}\text { Electronic Word of Mouth (E- } \\
\text { WOM) }\end{array}$ & 0.0000 \\
\hline
\end{tabular}

Source: Output SmartPLS 2.0, 2016. 
The table above give a value of 0,4547 to construct brand image, which mean that e-WOM capable of explaining the variance brand image by $45,47 \%$. R-square value is also available on purchase intention influenced by e-WOM and brand image in the amount of 0,3514 which mean that e-WOM and brand image able to explain the purchase intention variance of $35,14 \%$.

\section{Hypothesis Testing}

The first step is to examine the direct effect of e-WOM against purchase intention, reserchers estimates the direct effect e-WOM model to the purchase intention with the results as in figure 4 and table 9.

Table 9

Path Coefficient on Direct Effect Medel Tests Without Involving Mediation Variables.

\begin{tabular}{|l|c|c|c|c|c|}
\hline \multicolumn{1}{|c|}{ Variable } & $\begin{array}{c}\text { Original } \\
\text { Sample } \\
\text { (O) }\end{array}$ & $\begin{array}{c}\text { Sample } \\
\text { Mean (M) }\end{array}$ & $\begin{array}{c}\text { Standard } \\
\text { Deviation } \\
\text { (STDEV) }\end{array}$ & $\begin{array}{c}\text { Standard } \\
\text { Error } \\
\text { (STERRI) }\end{array}$ & $\begin{array}{c}\text { T Statistic } \\
\text { (IO/STERRI) }\end{array}$ \\
\hline $\begin{array}{l}\text { E-WOM -> Purchase } \\
\text { Intentions }\end{array}$ & 0,6023 & 0.6189 & 0.0597 & 0.0597 & 10.0754 \\
\hline
\end{tabular}

Source: Output SmartPLS 2.0, 2016

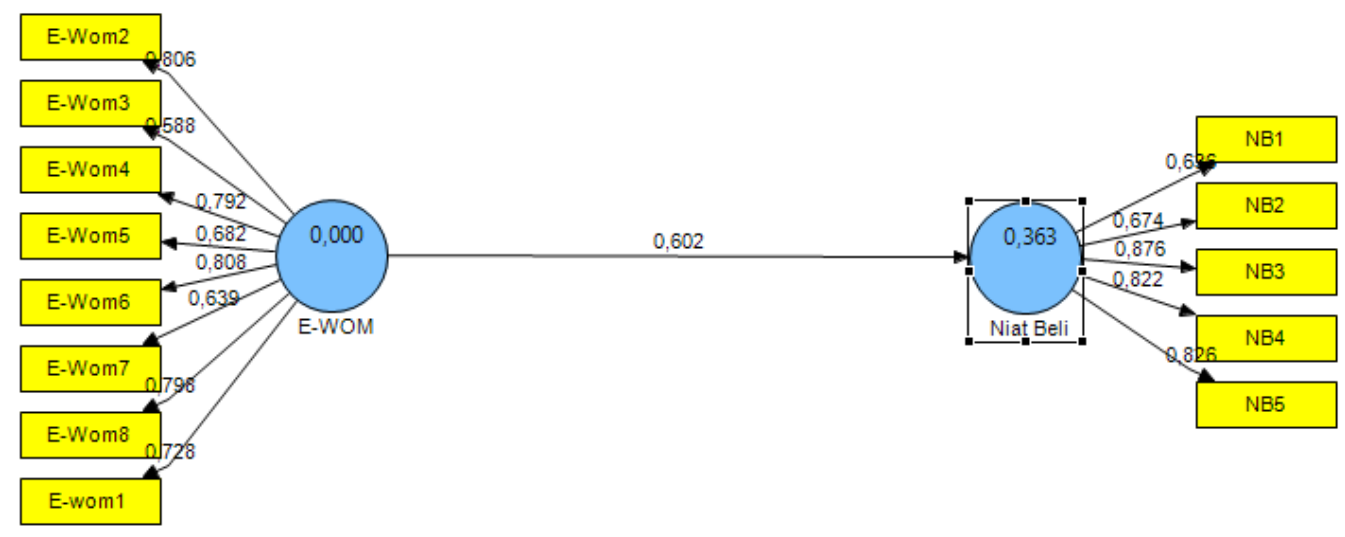

Figure 4: Results of Direct Effect Model Tests Without Involving Mediation variable Fifure 4 shows the direct effect of e-WOM $\rightarrow$ Purchase Intention with coefficient of 0,6023 and $\mathrm{t}$ statistic value gretaer tahan $\mathrm{t}$ table is $10,754>1,64$. Therefore, $\mathrm{H} 1$ is accepted. 


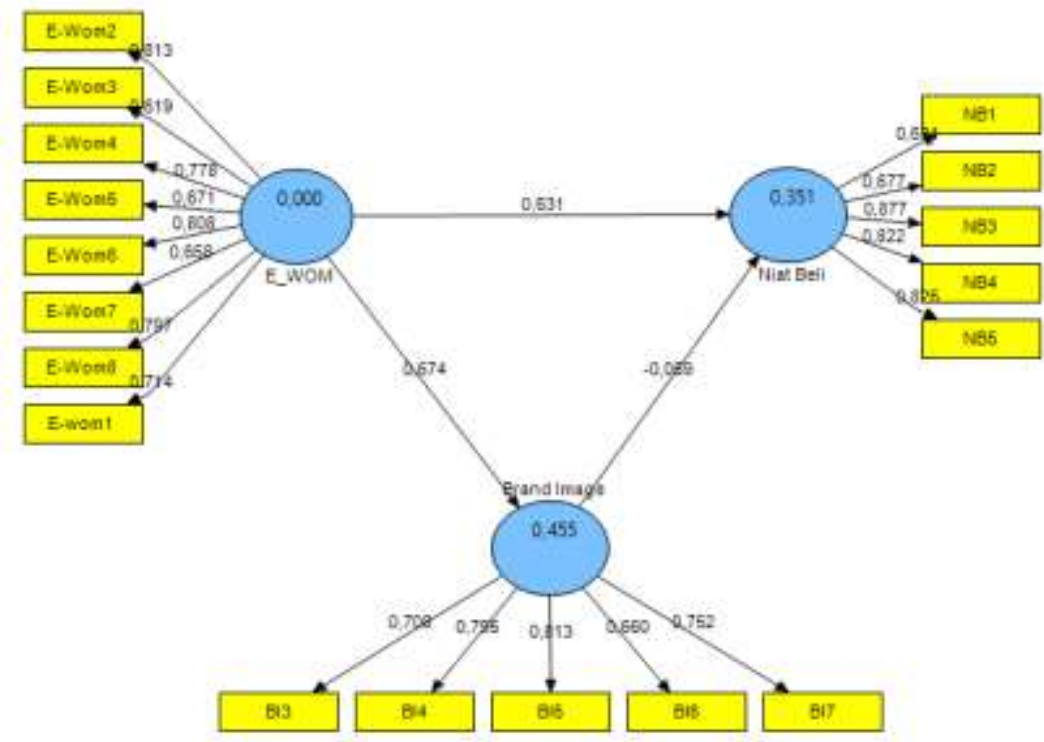

Figure 5: Simultaneous testing of Structural Model

Table 10

Path Coefficient

\begin{tabular}{|l|c|c|c|c|c|}
\hline \multicolumn{1}{|c|}{ Variable } & $\begin{array}{c}\text { Original } \\
\text { Sample } \\
\text { (O) }\end{array}$ & $\begin{array}{c}\text { Sample } \\
\text { Mean } \\
\text { (M) }\end{array}$ & $\begin{array}{c}\text { Standard } \\
\text { Deviation } \\
\text { (STDEV) }\end{array}$ & $\begin{array}{c}\text { Standard } \\
\text { Error } \\
\text { (STERRI) }\end{array}$ & $\begin{array}{c}\text { T Statistic } \\
\text { (IO/STERRI) }\end{array}$ \\
\hline E-WOM -> Brand Image & 0,6743 & 0,6720 & 0,1452 & 0,1452 & 11,0254 \\
\hline Brand Image -> Purchase Intention & $-0,0592$ & $-0,0561$ & 0,0611 & 0,0611 & 0,4075 \\
\hline E-WOM -> Purchase Intention & 0,6311 & 0,6384 & 0,1411 & 0,1411 & 4,470 \\
\hline
\end{tabular}

Source: Output SmartPLS 2.0, 2016.

In table 10 illustrates the amount of influence between variables tested simultaneously.

Submission on hypothesis 2 is supported and significant with value of beta coefficient equal to 0,6743 and t-statistic 11,0254 > t-table 1,64.

Submission on hypothesis 3 is not sifnificant because beta coefficient value equal to $-0,0592$ and t-statistic $0,4075<$ t-table 1,64 so hypothesis 3 is rejected.

Hyphotesis 4 wants to show the relationship between e-WOM variable as independent variable and purchase intention as dependent variable through brand image variable as mediating variable. In the testing of this mediation effect, the steps that have been done are: Testing the direct effect of the independent variable (e-WOM) on the dependent variable (Purchase Intention) on a model involving mediating variables (Brand Image), then the test effect of e-WOM to Brand Image and the effect of Brand Image to Purchase Intention

The results of calculation SmartPLS 2.0 software shows that the direct effect of the test e-WOM on Purchase Intention involving Brand Image showed a positive and significant effect with the beta coefficient value of 0,6311 with t-statistic 4,470 > t-table 1,64 (tabel 10).

Furthermore, in testing the direct effect of e-WOM on Purchase Intention without involving Brand Image variable shows positive and significant effect with beta coefficient value of 0,6023 
with t-statistic 10,0754 > t-table 1,64 (tabel 9). The results of testing the effect of Brand Image on Purchase Intentions showed negative effect and no significant effect with beta coefficient value equal to $-0,0592$ with t-statistic $0,4075<$ t-table 1,64 this cause mediation condition not fulfilled so hypothesis 4 not accepted.

Table 11

Results of Hypothesis testing Research

\begin{tabular}{|l|l|c|}
\hline \multicolumn{1}{|c|}{ Hypothesis } & Information \\
\hline H1 & $\begin{array}{l}\text { e-WOM on instagram account "Kulineratjeh" } \\
\text { effect on consumer Purchase Intention }\end{array}$ & Accepted \\
\hline H2 & $\begin{array}{l}\text { e-WOM on instagram account "Kulineratjeh" } \\
\text { effect on brand image instagram account } \\
\text { "Kulineratjeh". }\end{array}$ & Accepted \\
\hline H3 & $\begin{array}{l}\text { Brand image instagram account "Kulineratjeh" } \\
\text { effect on consumer Purchase Intention. }\end{array}$ & Not Accepted \\
\hline H4 & $\begin{array}{l}\text { e-WOM on instagram account "Kulineratjeh" } \\
\text { effect on consumer Purchase Intention through } \\
\text { brand image instagram account "Kulineratjeh" } \\
\text { as mediating variable. }\end{array}$ \\
\hline
\end{tabular}

Source: Primary Data, 2016

Here is a picture of the relationship between the variables of e-WOM between Purchase Intention with Brand Image as mediating variable which can be drawn on the following framework.

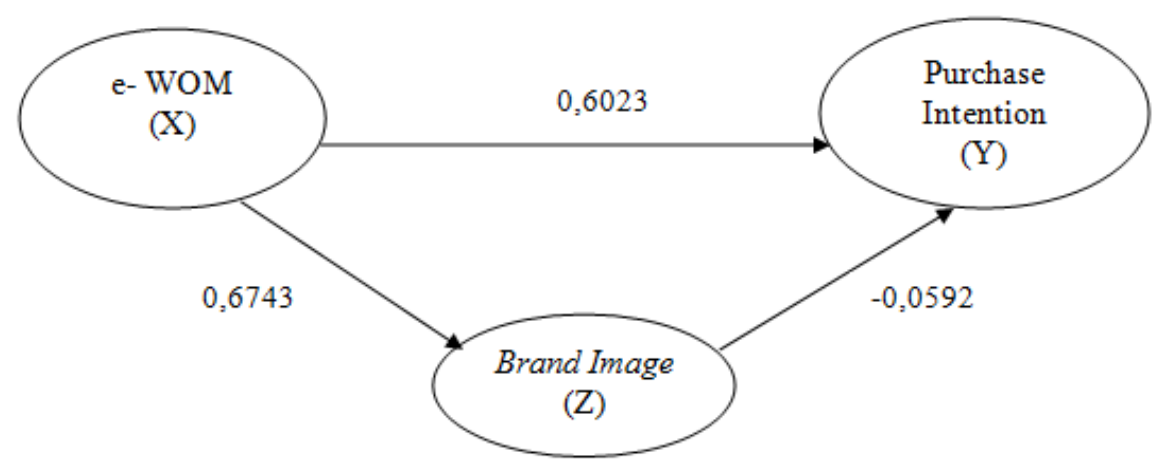

Figure 6 Concept of Theoretical Framework

The results of hyphothesis test 1 shows that e-WOM that happened on instagram account "Kulineratjeh" have positive and significant effect to Purchase Intentions. E-WOM is a conversation that occurs between consumers or potential customers on certain issues where the conversation take place via internet. This indicates that the activities of e-WOM that occured on instagram account "Kulineatjeh" trusted by consumer or prospective consumer and able to influence consumer Purchase Intention so e-WOM on instagram account "Kulineratjeh" become consumer consideration in form buying intention. This is because e-WOM considered more trustworthy than traditional WOM. The results of this hypothesis testing also supports the theory 
expressed by (Jalilvand 2012) in his research that the e-WOM growing influence on consumer Purchase Intentions. In addition, another study conducted by Widodo and Tomy (2012) also states there is significant influence of e-WOM on consumer Purchase Intention in the car industry. Based on the other studies conducted by Jatmika (2014), e-WOM also significantly influence consumer purchasing intentions smart phone Samsung in the city of Surabaya.

The result of hypothesis 2 test shows that e-WOM has positive and significant effect on Brand Image. E-WOM that occurs on instagram account "Kulineratjeh" effect on Brand Image instagram account "Kulineratjeh" is a provider of halal culinary information, complete and interesting in Banda Aceh. Up to date information on instagram account "Kulineratjeh" makes consumer perception of Brand Image instagram account "Kulineratjeh" good. The results of testing this hypothesis is also supported by Hatane Samuel and Adi Suryanata which states that the e-WOM directly affect the Brand Image (2014). Another study conducted by Jalilvand (2012), also states e-WOM is the most effective factor affecting the Brand Image of the automobile industry in Iran. The other study was conducted by Jatmika (2014), stating that e-WOM is also a factor that is most effective in influencing Brand Image the products smart phone Samsung in Surabaya. In addition, another study conducted by Naimatullah Charo et al (2015) e-WOM significant effect on Brand Image of the site opinions online.

The result of hypothesis 3 testing shows that Brand Image has no effect on consumer Purchase Intention. The resulting coefficient values in the third hypothesis is -0,0592 and t-statistics 0,4075 $<\mathrm{t}$-table 1,64 so that hypothesis 3 is rejected. The results of this study is different from prevoius research conducted by Charo, Sharma, Shaikh, Haseeb, \& Sufya (2015) which states that Brand Image on online review affect the consumer Purchase Intention. In this study that affect consumer Purchase Intention is e-WOM that developed on instagram account "Kulineratjeh" while Brand Image has not been able to affect consumer Purchase Intention. Therefore instagram account "Kulineratjeh" less give price information on culinary which is promoted and sample in this research more dominated by respondent with type of work as student/ student with percentage of $60 \%$ cause Brand Image instagram account "Kulneratjeh" not yet able to influence consumer Purchase Intention. This is because the income owned by $60 \%$ of respondents is still very limited, so this has not been able to affect consumer Purchase Intention. The results of this research is supported by research conducted by Arista (2011) which also stated that Brand Image has no effect on Purchase Intention to Telkom Speedy consumer in Semarang City.

Hypothesis 4 testing did nit show any effect of e-WOM on Purchase Intention through Brand Image. Because in this research is not found the influence of Brand Image variable on Purchase Intention so that mediation requirement is not fulfilled. This is because that e-WOM that occurs on instagram account "Kulineratjeh" trusted and believed by consumers as the most complete culinary information provider in Banda Aceh so that e-WOM give a direct influence to consumer Purchase Intention without going through Brand Image instagram account "Kulineratjeh". This causes the mediation condition to be unfulfilled.

Thus, this research indicates that e-WOM which happened on instagram account "Kulineratjeh" has direct effect to consumer Purchase Intention. This indicates that the increasing number of business owners who do promotion on instagram account "Kulineratjeh" will cause the increasing intention of consumers to make a purchase. This is because consumers believe that eWOM on instagram account "Kulineratjeh" able to influence consumers in shaping purchase intentions. In addition, e-WOM on instagram account "Kulineratjeh" is also able to increase Brand 
Image instagram account "Kulineratjeh" as a provider of halal culinary refence information and the most complete in Banda Aceh and surrounding, but brand image owned instagram account "Kulineratjeh" has not been able affect consumer Purchase Intention.

\section{Conclusion}

1. E-WOM is one of the marketing communication activities are envolving from traditional WOM. E-WOM is considered more effective than the traditional WOM. This is because the e-WOM has a wider range than traditional WOM and is considered more credible so e-WOM can influence consumers in shaping Purchase Intentions.

2. Based on test result that have been performed using the SmartPLS 2.0 shows that the presence of positive and significant influence directly between the existing e-WOM on instagram account "Kulineratjeh" agains consumer purchasing intentions with a coefficient of 0,6311 and the value of statistic greater than $4,470 \mathrm{t}$ table is 1,64 . It concludes that any potential customers who see e-WOM is on the instagram account "Kulineratjeh" affect their Purchase Intentions.

3. E-WOM has significant effect on Brand Image with beta coefficient value of 0,6743 and $t-$ statistics $11,0254>1,64$.

4. In this study, Brand Image has not been able to influence consumer. This is because the value of the beta coefficient obtained by $-0,0592$ and t-statistics $0,4075<1,64$. These results also causes the mediation requirement to be unfulfilled.

\section{Suggestions}

In order to further interest, there are some suggestions submitted by the author that would be considered by the next researcher, as allows:

1. In the absence of the influence of Brand Image on Purchase Intention, it is suggested to further researcher to further explore similar topics with the addition of other variables.

2. The author suggests to the next researcher to do more in-depth research on e-WOM using other social media.

3. Future researchers are recommended to conduct the research in a large sample size so its more accurate.

4. The authors suggest to the administrator of instagram account "Kulineratjeh" to further build Brand Image instagram account "Kulineratjeh" so that consumers are more confident in shaping Purchase intentions.

5. The author suggested to business owners engaged in culinary to increase their promotional activities to build e-WOM with social media, especially instagram.

\section{Corresponding Author}

Nanda Khalisa

Economics \& Business Faculty

Syiah Kuala University, Banda Aceh, Indonesia

Email: nandakhalisa12@yahoo.com 
INTERNATIONAL JOURNAL OF ACADEMIC RESEARCH IN BUSINESS AND SOCIAL SCIENCES

Vol. 8, No. 5, May 2018, E-ISSN: 2222-6990 @ 2018 HRMARS

\section{References}

Abdillah, W., \& Jogiyanto. (2015). Partial least square (PLS): Alternative strustural equation modelling (SEM) dalam penelitian bisnis. Yogyakarta: Penerbit Andi.

Bambauer-Sachse, S., \& Mangold, S. (2011). Brand equity dilution through negative online wordof-mouth communication. Journal of Retailing and Consumer Services, 18, 38-45.

Baron, M. R., \& David, A. K. (1986). The Moderator-Mediator variable distinction in social psychological research: Conceptual, strategic, and statistical considerations. Journal of Personality and Social Psychology, 51, 1173-1182.

Bhakar, S. S., Bhakar, S., \& Bhakar, S. (2013). Relationship between country of origin, brand image and customer purchase intentions. Journal of Psychology and Business, 10(2), 25-47.

Carmines, E. G., \& Zeller, R. A. (1979). Reliability and validity assessment. Sage Publications.

Charo, N., Sharma, P., Shaikh, S., Haseeb, A., \& Sufya, M. Z. (2015). Determining the impact of ewom on brand image and purchase intention through adoption of online opinions. International Journal of Humanities and Management Sciences (IJHMS), 3(2), 2320-4044.

Dharmmesta, B. S. (2002). Azas-Azas marketing. Yogyakarta: Penerbit Liberty.

Goldsmith, E. R., \& Horowitz, D. (2006). Measuring motivations for online opinion seeking. Journal of Interactive Advertising, 6(2), 3-14.

Gozali, M. Y., \& Ruslim, T.S. (2012). Efek E-WOM Terhadap Brand Image dan Purchase Intention. Jakarta: Karya IImiah Dosen Fakultas Ekonomi.

Hendriyani, J., Ceng, L, Utami, N., Priskila, R., \& Anggita, S. (2013). Online consumer behavior: Confirming the aisas model on twitter users. International Conference on Social and Political Sciences (ICSPS). West Java.

Hermawan, A. (2012). Komunikasi pemasaran. Jakarta: Airlangga.

Hussein, S. A. (2015). Modul ajar penelitian bisnis dan manajemen menggunakan partial least squares (p/s) dengan smartpls 3.0. Fakultas Ekonomi dan Bisnis Universitas Brawijaya.

Jakpat. Survey result by jakpat. Diakses daripada http://blog.jakpat.net/en/> [2016/413]

Jalilvand, M. R., \& Samiei, N. (2012). The effect of electronic word of mouth on brand image and purchase intention an empirical study in the automobile industry in Iran. Journal of Marketing Intelligence \& Planning, 30(4), 460-476.

Jatmika, S. C. (2014). Pengaruh electronic word of mouth terhadap brand image dan purchase intention smartphone Samsung di Surabaya. Jurnal Ilmiah Mahasiswa Universitas Surabaya, 3(2), 1-15.

Keller, K. L. (2013). Strategic Brand Management: Building, Measuring, and Managing Brand Equity( $4^{\text {th }}$ ed.). United States: Pearson Education, Inc.

Lin, Chino, Yi-Shuang, W., \& Chen, J. V. (2013). Electronic word-of-mouth: The moderating roles product involvement and brand image. Paper presented at International Conference on Technology Innovation and Industrial Management, Phuket, Thailand on 29-3 May 2013.

Malhotra, N. K. (2009). Riset pemasaran pendekatan terapan. Jakarta: PT Index.

Moksaoka, I. M. W., \& Rahyuda, I. K. (2016). Peran brand image dalam memediasi country of origin terhadap purchase intention. E-Jurnal Manajemen Unud, 5(3), 1690-1716.

Morrisan. (2012). Periklanan, komunikasi pemasaran terpadu. Jakarta: Kencana.

Nashiruddin, K., \& Hashim, H. (2015). Electronic word of mouth: Exploring consumer reactions and purchase intention. Journal of Global Business and Social Entrepreneurship (GBSE), 1, 85-93. 
INTERNATIONAL JOURNAL OF ACADEMIC RESEARCH IN BUSINESS AND SOCIAL SCIENCES

Vol. 8, No. 5, May 2018, E-ISSN: 2222-6990 @ 2018 HRMARS

Onad. Mobile Marketing. Diakses dari http://mobimarketing.blogspot.co.id/

Park, D. H., \& Kim, S. (2008). The effect of consumer knowledge on message processing of electronic word of mouth via online consumer reviews. Electronic Commerce Research and Aplications, 7, 399-410.

Peter, P. J., \& Olson, J. C. (2013). Perilaku konsumen \& strategi pemasaran (Edisi Ke-9). Jakarta: Salemba Empat.

Philip, K., \& Armstrong, G. (2008). Prinsip-Prinsip Pemasaran (Edisi ke-12). Jakarta: Airlangga.

Philip, K., \& Keller, K. L. (2008). Manajemen pemasaran. Jakarta: Prenhall Indo.

Philip, K., \& Kevin, K. L. (2009). Manajemen pemasaran. Jakarta: Prenhall Indo.

Philip, K., (2004). Manajemen pemasaran. Jakarta: Prenhall Indo.

Philip, K., Armstrong, G., Adam, S., \& Denize, S. (2015). Principles of Marketing (6 ${ }^{\text {th }}$ Ed). Australia: Pearson. Diakses daripada https://books.google.com/

Prendergast, G., Ko, D., \& Yuen, S. Y. V. (2010). Online word of mouth and consumers purchase intentions. International Journal of Advertising, 29(5), 687-708.

Pursiainen, E. (2010). Consumer motivation for providing electronic word of mouth in virtual pet communities. Marketing Master's Thesis. Alto University School of Economics.

Putranti, Dwi, H. R., \& Pradana, F. D. (2015). Electronic word of mouth (e-wom), kepuasan konsumen dan pengaruh langsung dan tak langsung terhadap minat beli konsumen. Media Ekonomi dan Manajemen, 30, 101-113.

Rizal, V. Z., \& Lubis, E. E. (2014). Social media marketing twitter dan brand image restoran burger. Jurnal Ilmu Komunikasi, 5(1), 103-118.

Samuel, H., \& Lianto, A. S. (2014). Analisis eWOM, brand image, brand trust dan minat beli produk smart phone di Surabaya. Jurnal Manajemen Pemasaran, 8(2), 47-54.

Sangadji, E. M. \& Sopiah. (2013). Perilaku Konsumen Pendekatan Praktis. Jakarta: Penerbit Andi.

Schiffman, L. G., \& Kanuk, L. L. (2004). Perilaku konsumen (Edisi ke-7). Jakarta: PT Index.

Schiffman, L. G., \& Kanuk, L. L. (2007). Consumer behaviour. USA: New Jersey Prentice Hall.

Schiffman, L. G., \& Kanuk, L. L. (2010). Consumer behaviour. USA: Pearson Prentice Hall.

Sekaran, U., \& Bougie, R. (2009). Research methods for business: A skill building approach. United Kingdom: John Wiley.

Sugiyono. (2016). Metode penelitian pendidikan: Pendekatan kuantitatif, kualitatif, dan R\&D. Bandung: Alfabeta.

Suharsimi, A. (2002). Prosedur penelitian suatu pendekatan praktek. Jakarta: Rineka Cipta.

Suharsimi, A. (2013). Prosedur penelitian suatu pendekatan praktik. Jakarta: Rineka Cipta.

Tariq, M. I., Nawaz, M. R., Nawaz, M. M., \& Butt, H. A. (2013). Customer perceptions about branding and purchase intention: A study of FMCG in an emerging market. Journal of Basic and Applied Scientific Research, 3(2), 340-347.

Tatik, S. (2013). Perilaku konsumen di era internet implikasinya pada strategi pemasaran. Yogyakarta: Graha Ilmu.

Thurau, T. H., Gwinner, K. V., Walsh, G., \& Gremler, D. D. (2004). Electronic word of mouth via consumer-opinion platform: what motivates consumers to articulate themselves on the internet?. Journal of Interactive Marketing, 18(1), 1002-10073.

Tjiptono, F. (2008). Strategi pemasaran. Yogyakarta: Penerbit Andi.

Tjiptono, F. (2011). Manajemen \& strategi merek. Yogyakarta: Penerbit Andi 
Wijaya, T., \& Paramita, E. L. (2014). Pengaruh Electronic Word of Mouth (e-WOM) Terhadap Keputusan Pembelian Kamera DSLR. Seminar Nasional dan Call for Paper (Sancall). Salatiga. Wikipedia. Media Sosial. Diakses dari https://id.wikipedia.org/wiki/Media_sosial

Zhang, R., \& Tran, T. (2009). Helping e-commerce make good purchase decisions: A user reviewsbased approach. Verlag Berlin Heidelberg, 26(1), 1-11.

Zhang, Z., Qiang, Y., Rob, L., \& Yijun, L. (2010). The impact of e-word-of-mouth on the online popularity of restaurant: A comparison of consumers reviews and editor reviews. International Journal of Hospitality Management, 29, 694-700.

\section{About the Author(s)}

Nanda Khalisa, (S.E, Economics \& Business Faculty, Syiah Kuala University, Banda Aceh, Indonesia, 2016) is currently a Master of Management student at Magister Management Study, Syiah Kuala University, Banda Aceh. Email: nandakhalisa12@yahoo.com

Teuku Meldi Kesuma (PhD) is a lecturer in Economics \& Business Faculty, Syiah Kuala University, Banda Aceh, Indonesia. Specialized in Marketing Communication.

Email: teukumeldi@unsyiah.ac.id 